\title{
Squamous Cell Carcinoma of the Tongue After Bone Marrow Transplantation in a Patient with Fanconi Anemia
}

\author{
Fernanda Gonçalves SALUM ${ }^{1}$ \\ Gabriela Botelho MARTINS ${ }^{2}$ \\ Maria Antonia Zancanaro de FIGUEIREDO ${ }^{1}$ \\ Karen CHERUBINI ${ }^{1}$ \\ Liliane Soares YURGEL ${ }^{1}$ \\ Cassius TORRES-PEREIRA ${ }^{3}$ \\ ${ }^{1}$ Discipline of Clinical Oral Pathology, Clinical Department, Faculty of Dentistry, \\ Pontifical Catholic University of Rio Grande do Sul, Porto Alegre, RS, Brazil \\ ${ }^{2}$ Discipline of Clinical Oral Pathology, Dental School, Bahia \\ State Foundation for Science Development (FBDC), Salvador, BA, Brazil \\ ${ }^{3}$ Department of Clinical Oral Pathology, Dental School, Federal University of Paraná, PR, Brazil
}

\begin{abstract}
Fanconi anemia (FA) is an autosomal recessive disorder that might cause a variety of congenital and developmental abnormalities. The most important features of FA are progressive bone marrow failure and development of malignancies, particularly acute myeloid leukemia and solid tumors. This paper reports the case of a 12-year-old patient with FA assisted at the Stomatology and Bucomaxillofacial Cancer Prevention Service of São Lucas Hospital, Brazil, who had been submitted to bone marrow transplantation (BMT) at the age of 5 and exhibited oral lesions characteristic of chronic graft versus host disease (GVHD). The patient was treated and followed-up for the oral lesions. Eleven years after the BMT, he developed squamous cell carcinoma of the tongue with an aggressive behavior, which was considered an untreatable condition. The patient died few months later from asphyxia at the age of 16 . The reasons for development of these malignant conditions are unknown. However, chromosomal instability typically observed in FA cases, BMT factors and GVHD have been considered. Systematic follow-up of these patients allows early and less invasive therapeutic approaches.
\end{abstract}

Key Words: Fanconi anemia, squamous cell carcinoma, bone marrow transplantation.

\section{INTRODUCTION}

Fanconi anemia (FA) is a genetically and phenotypically heterogeneous autosomal recessive disorder. Seven genes have been identified to be associated with the disease, which are responsible for defects in at least eight FA complementation groups (A, B, C, D1, D2, E, F, G) (1). FA proteins have a significant role in DNA recombination/repair and cell cycle. Cells of patients with this condition are characterized by hypersensitivity to DNA cross-linking agents, resulting in chromosomal breakages that provide the basis for the diagnostic test (2).
Patients with FA may show a variety of congenital and developmental abnormalities such as skeletal, renal, gastrointestinal, cardiac and genital anomalies, skin pigmentation defects, short stature, microphthalmia and mental retardation. Up to one third of affected patients do not have any obvious abnormalities and therefore, diagnosis is suspected when they develop hematologic problems (2). The most important feature of FA is the progressive bone marrow failure, which leads to aplastic anemia and myelodysplastic syndrome usually during childhood. The development of malignancies, particularly acute myeloid leukemia and solid tumors, is also a relevant characteristic of this

Correspondence: Profa. Dra. Maria Antonia Zancanaro de Figueiredo, Avenida Ipiranga, 6690, Sala 231, Serviço de Estomatologia do Hospital São Lucas, PUCRS, 90610-000 Porto Alegre, RS, Brasil. Tel/Fax: +55-51-3320-3254. e-mail: mazfig@terra.com.br 
condition. While the risk for hematologic anomalies is greater during childhood, solid tumors are most frequently observed in adults (3). Squamous cell carcinoma (SCC) is the most commonly found solid neoplasm in patients with FA, occurring mainly in the head and neck region (4).

Bone marrow transplantation (BMT) is the definitive treatment of choice for patients with FA who develop hemopoietic failure. However, this therapeutic modality may predispose to late development of malignancies by adding risk factors, such as pretransplantation conditioning with chemotherapy and radiotherapy, immunosuppressive agents given for prophylaxis of graft versus host disease (GVHD) and GVHD itself $(5,6)$. This disease is a common complication in patients treated with allogeneic BMT. There is an attack of donor $\mathrm{T}$ lymphocytes in various recipient tissues because of differences in major and minor histocompatibility antigens (7).

This paper describes the case of a BMT patient with Fanconi anemia who showed oral lesions compatible with GVHD and developed a squamous cell carcinoma of the tongue. Possible factors that may have led to neoplasm occurrence are also discussed.

\section{CASE REPORT}

A 12-year-old male Caucasian patient was referred by the Hematology Service to the Stomatology and Bucomaxillofacial Cancer Prevention Service of São Lucas Hospital, (Brazil) for examination of asymptomatic white lesions on his tongue with two months of evolution.

Review of the patient's medical history revealed that he had been submitted to BMT at the age of 5 to treat FA and had a sister who died from the same disease. He received cyclophosphamide for pretransplant conditioning and cyclosporin and methotrexate for posttransplant prophylaxis against GVHD. Four months after BMT, he showed discreet lichenoid lesions on buccal mucosa, which were compatible with chronic GVHD and did not require treatment. Ten months after BMT, the oral lesions aggravated and systemic corticoid was prescribed for 3 months.

At the time of the first examination at our Stomatology Service, 7 years after BMT, the patient was using interferon for treatment of C-type hepatitis. Intraoral examination showed a white plaque, with rugged surface on the left side of the dorsum of the tongue, measuring $1.2 \times 1.0 \mathrm{~cm}$ (Fig. 1). The tongue was also smooth. The lesion was clinically compatible with leukoplakia, chronic GVHD or hypertrophic oral lichen planus (OLP). The patient did not attend the subsequent consultations.

Ten months later, the patient returned exhibiting erosive lesions with striated borders and lichenoid aspect on the hard palate (Fig. 2). He also had an ulcer on the right buccal mucosa and erythema of gingiva and upper lip. Incisional biopsy of the tongue lesion revealed keratinized squamous cell epithelium and at the chorion, chronic inflammatory infiltration, angiogenesis and melanic pigmentation (Fig. 3). These features are compatible with either chronic GVHD or OLP. The fact that the patient had undergone BMT justified the diagnosis of GVHD, as the literature describes that these lesions show clinical features similar to those found in OLP. Therefore, the lesions were controlled, exhibiting remission and overstatement periods. For symptomatic treatment, the patient used dexamethasone elixir and fludroxycortide cream for the lips and the lesions showed clinical remission.

Four years after the diagnosis of the lichenoid lesions and 11 years after BMT, the 16-year-old patient presented with a mass on the womb and dorsum of the tongue, on the left side, exhibiting ulcerated areas and with 15 days of evolution (Fig. 4). A new biopsy was indicated, but the procedure was postponed because of the patient's bad systemic conditions. The patient returned one month later and the lesion was examined after an incisional biopsy. The patient was diagnosed as having a $\mathrm{T}_{3} \mathrm{~N}_{0} \mathrm{M}_{0}$ squamous cell carcinoma of the

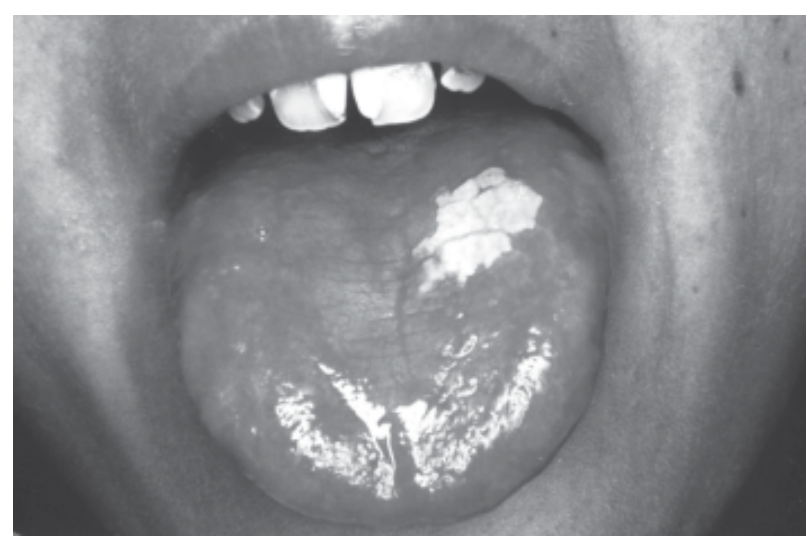

Figure 1. White plaque lesion on the left side of the tongue dorsum. Note tongue smoothness. 
tongue (Fig. 5), which was considered an untreatable condition. For palliative treatment, the patient received chemo and radiotherapy and a clinical remission of the tumor was observed. Shortly after, a new ulcer developed in the same area, which had grown rapidly and showed necrosis and infiltrated borders. The patient died four months later from asphyxia at the age of 16 .

\section{DISCUSSION}

FA is a highly heterogeneous syndrome, in which homozygotes may show congenital anomalies and hematological problems. The main cause of morbity and

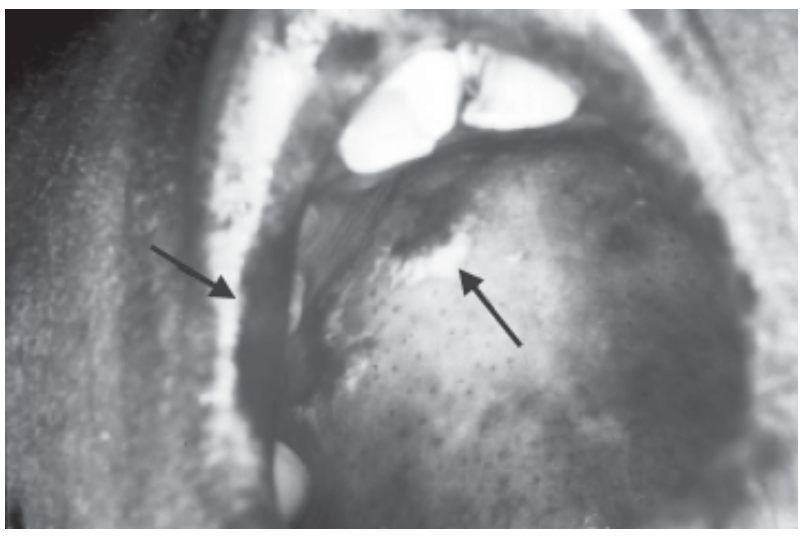

Figure 2. Intraoral view showing lesions with striated borders and lichenoid aspect on the hard palate and erythema on the upper lip, which were compatible with prophylaxis of graft versus host disease (arrows).

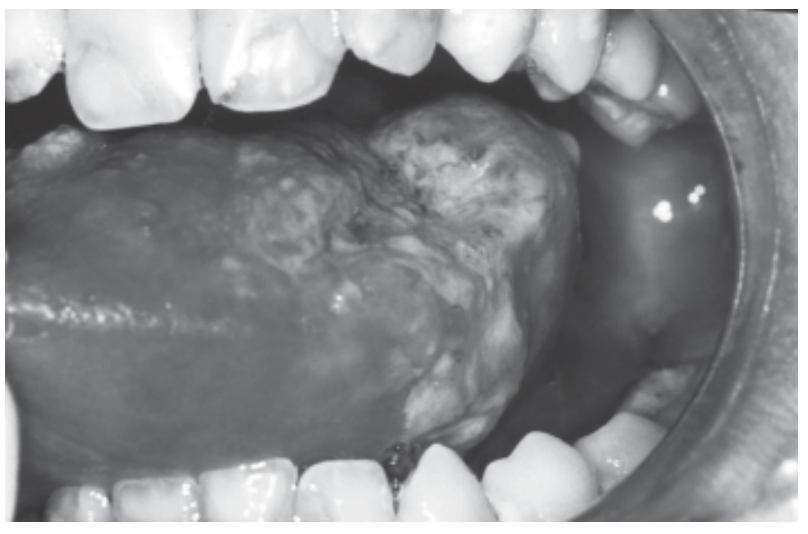

Figure 4. Intraoral lateral view showing a lesion compatible with squamous cell carcinoma on the womb and dorsum of the tongue, on the left side, exhibiting ulcerated areas and rolled borders. mortality are aplastic anemia, myelodysplasia and malignancies (2). Although acute myeloid leukemia is the most commonly found malignancy, solid tumors represent about $40 \%$ of neoplasms observed (1), which develop at older ages in patients surviving the hematologic abnormalities (2).

Pancytopenia typically manifests between the ages of 5 and $10(8,9)$. In the case reported in this paper, FA was diagnosed in an early stage. At 1 month of life, anemia was considered and the $3 \frac{1}{2} 2$ year-old patient had already undergone 11 blood transfusions. The patient showed frequent epistaxis and ecchymosis, which are common in these cases (2).

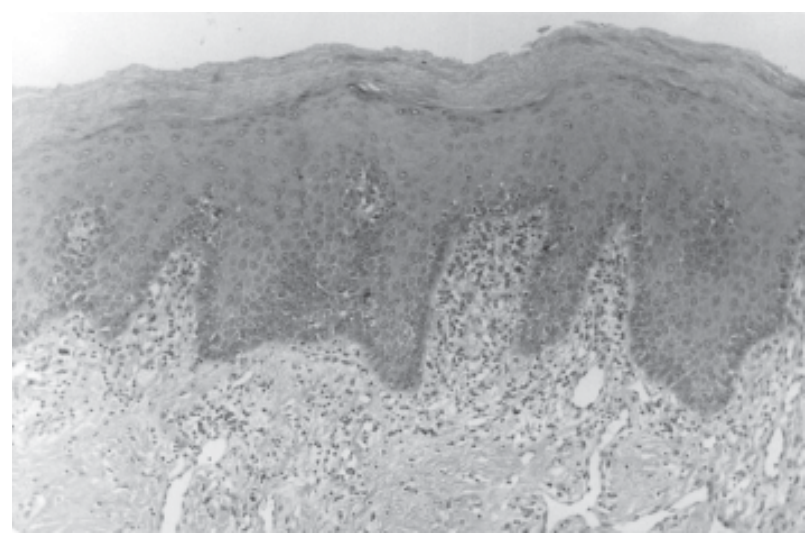

Figure 3. Photomicrograph exhibiting keratinized squamous cell epithelium, chronic inflammatory infiltration and melanic pigmentation at the corium (Hematoxylin and eosin staining. Original magnification X200).

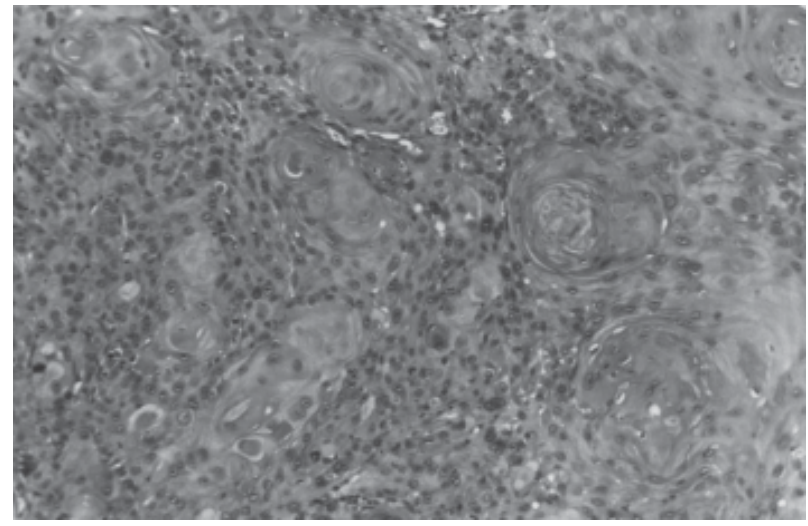

Figure 5. Photomicrograph of squamous cell carcinoma showing proliferation of neoplastic squamous cells with pleomorfism, hyperchromatism, atypical mitosis and keratin pearls (Hematoxylin and eosin staining. Original magnification X200). 
A lesion showing aggressive behavior developed on the patient's lateral border of tongue at age of 16 . Studies have shown that FA patients who survive into early adulthood have an increased risk of developing solid tumors, particularly SCC of oropharynx and anogenital regions $(1,3)$. A review of literature (4) revealed 29 cases of SCC in FA patients. Fifteen of these cases involved oral carcinoma, with tongue being the most frequently affected site. As observed in the case presented in this paper, SCC associated with FA develops earlier than in general population and shows a more aggressive behavior $(10,11)$. Furthermore, in contrast to FA-nonaffected individuals, predisposing risk factors for head and neck cancer, like tobacco and alcohol abuse, are rare in these patients (4).

In this report, development of malignancy occurred 11 years after BMT, which is a longer period than that observed by Deeg et al. (5), who reported that malignancy development occurred in a peak between 8 and 9 years after BMT. These authors suggested that factors related to BMT, such as pretransplant irradiation and immunosuppressive therapy (azathioprine) may increase the risk for late tumor development in patients with aplastic anemia and FA. However, they did not compare the risk of malignancies in FA patients who underwent BMT and patients who did not receive bone marrow transplant.

Such comparison was made in other studies $(1,10)$, which showed that the percentage of BMT patients who developed solid tumors was $2.7 \%$, while the percentage of non-BMT patients who developed solid tumors was $13 \%$. The authors suggested that the underlying chromosomal instability, typical of FA, may play a more important role in the development of solid tumors than factors associated to BMT. Reviewing 30 cases of carcinoma in FA, Jansisyanont et al. (6) found that the lesions occurred before BMT in 22 patients and after BMT in 6 cases. Socie et al. (12) estimated that the risk for development of solid neoplasms in patients submitted to BMT (aplastic anemia) is 22-fold higher than in that observed in general population. More studies evaluating the role of BMT in cancer development in FA patients are required.

Immunosuppressive drugs administered for prophylaxis or treatment of GVHD are also associated to an increased risk of malignancies. Most patients who develop malignancy after BMT also have chronic GVHD $(5,13)$. Additionally, some authors have observed the development of such tumors on sites initially involved with GVHD-related inflammatory processes $(7,14)$. The patient presented in this case report showed a white plaque on the tongue in addition to erosive areas with striated borders on other oral sites, which persisted for almost 4 years until SCC development.

The challenge was the differential diagnosis between chronic GVHD and OLP because OLP is more frequent in the mouth than GVHD, despite the early age of the patient. Due to its association with OLP, the presence of C-hepatitis virus has been suggested in several reports (15-17). The histopathologic pattern in first biopsy was not completely elucidatory, being compatible with both OLP and GVHD. Neville et al. (18) suggested that the difference between both conditions is specifically the inflammatory reaction, which is not so intense in GVHD. To settle the diagnosis of chronic GVHD, it must be taken into account that the patient had undergone BMT and the lesions may develop several years after this procedure.

Despite the cause of malignancy, a systematic follow-up of FA patients is essential because it allows early therapeutic intervention when necessary, which may result in improved survival rate or at least reduce the need for more aggressive approaches. In the reported case, in spite of the regular follow-up, it was not possible to stop the aggressive tumor progression, which, in only few months, reached dimensions that made any curative therapeutic intervention impossible. Abdelsayed et al. (7) advocated that oral cancer in patients with GVHD may have an aggressive biologic potential with increased tendency for recurrence and development of new lesions.

In the same way of previous reported cases $(4,6)$, the patient of this study displayed multiple risk factors for SCC development, including genetic predisposition, pretransplant conditioning with cyclophosphamide and chronic GVHD. The question of whether carcinoma is caused by BMT factors, FA nature or both still needs further investigation.

\section{RESUMO}

A anemia de Fanconi (AF) é uma doença autossômica recessiva heterogênea que pode causar uma variedade de alterações congênitas e de desenvolvimento. As características mais importantes da AF são a falência progressiva de medula óssea e o desenvolvimento de condições malignas, como leucemia mielóide aguda e tumores sólidos. Este artigo relata o caso de um 
paciente de 12 anos com AF atendido no Serviço de Estomatologia e Prevenção do Câncer Bucomaxilofacial do Hospital São Lucas (Brasil), que havia sido submetido a transplante de medula óssea (TMO) aos 5 anos e apresentaava lesões características da doença do enxerto versus hospedeiro (DEVH) crônica. O paciente foi regularmente acompanhado no Serviço e, 11 anos após a realização do TMO, desenvolveu um carcinoma epidermóide de língua, considerado com sendo uma condição não-tratável. O pactiente faleceu por asfixia poucos meses depois aos 16 anos. As razões para a ocorrência dessa condição maligna ainda são incertas, podendo estar relacionadas com a instabilidade cromossômica característica da AF, com fatores relacionados ao TMO ou com a DEVH. O acompanhamento sistemático desses pacientes permite a realização de abordagens terapêuticas precoces e menos agressivas quando necessário.

\section{REFERENCES}

1. Kutler DI, Singh B, Satagopan J, Batish SD, Berwick M, Giampietro PF, Hanenberg H, Auerbach AD. A 20-year perspective on the International Fanconi Anemia Registry (IFAR). Blood 2003;101:1249-1256.

2. Tischkowitz MD, Hodgson SV. Fanconi anaemia. J Med Genet 2003;40:1-10.

3. Rosenberg PS, Greene MH, Alter BP. Cancer incidence in persons with Fanconi anemia. Blood 2003;101:822-826.

4. Millen FJ, Rainey MG, Hows JM, Burton PA, Irvine GH, Swirsky D. Oral squamous cell carcinoma after allogenic bone marrow transplantation for Fanconi anemia. Br J Haematol 1997;99:410-414.

5. Deeg HJ, Socié G, Schoch G, Henry-Amar M, Whiterspoon RP, Devergie A, Sullivan KM, Gluckman E, Storb R. Malignancies after marrow transplantation for aplastic anemia and Fanconi anemia: a joint Seattle and Paris analysis of results in 700 patients. Blood 1996;87:386-392.

6. Jansisyanont P, Pazoki A, Ord RA. Squamous cell carcinoma of the tongue after bone marrow transplantation in a patient with Fanconi’s anemia. J Oral Maxillofac Surg 2000;58:14541457.

7. Abdelsayed RA, Sumner T, Allen CM, Treadway A, Ness GM, Penza SL. Oral precancerous and malignant lesions associated with graft-versus-host disease: report of 2 cases. Oral Surg Oral Med Oral Pathol Oral Radiol Endod 2002;93:75-80.

8. Auerbach AD, Allen RG. Leukemia and preleukemia in
Fanconi anemia patients. A review of the literature and report of the International Fanconi Anemia Registry. Cancer Genet Cytogenet 1991;51:1-12.

9. Butturini A, Gale RP, Verlander PC, Alder-Brecher B, Gillio AP, Auerbach AD. Hematologic abnormalities in Fanconi anemia: an International Fanconi Anemia Registry study. Blood 1994;84:1650-1655.

10. Kutler DI, Auerbach AD, Satagopan J, Giampietro PF, Batish SD, Huvos AG, Goberdhan A, Shah JP, Singh B. High incidence of head and neck squamous cell carcinoma in patients with Fanconi anemia. Arch Otolaryngol Head Neck Surg 2003;129:106-112.

11. Alter BP. Fanconi's anemia and malignancies. Am J Hematol 1996;53:99-110.

12. Socie G, Henry-Amar M, Devergie A, Wibault P, Neiger M, Cosset JM, Gluckman E. Poor clinical outcome of patients developing malignant solid tumours after bone marrow transplantation for severe aplastic anaemia. Leuk Lymph 1992; 7:419-423.

13. Zhang L, Epstein JB, Poh CF, Berean K, Lam WL, Zhang X, Rosin NP. Comparison of HPV infection, P53 mutation and allelic losses in post-transplant and non-posttransplant oral squamous cell carcinomas. J Oral Pathol Med 2002;31:134141.

14. Otsubo H, Yokoe H, Miya T, Atsuta F, Miura N, Tanzawa H, Sato K. Gingival squamous cell carcinoma in a patient with chronic graft-versus-host disease. Oral Surg Oral Med Oral Pathol Oral Radiol Endod 1997;84:171-174.

15. Bagan JV, Ramon C, Gonzalez L, Diago M, Milian MA, Cors R, Lloria E, Cardona F, Jimenez Y. Preliminary investigation of the association of oral lichen planus and hepatitis C. Oral Surg Oral Med Oral Pathol Oral Radiol Endod 1998;85:532536.

16. Henderson I, Muir M, Mills PR, Spence E, Fox R, McCruden EA, Bagg J. Oral health of patients with hepatitis C virus infection: a pilot study. Oral Dis 2001;7:271-275.

17. Seoane J, Romero MA, Varela-Centelles P, Diz-Dios P, Garcia-Pola MJ. Oral lichen planus: a clinical and morphometric study of oral lesions in relation to clinical presentation. Braz Dent J 2004;15:9-12.

18. Neville BW, Dam DD, Allen CM, Bouquot JE. Oral and Maxillofacial Pathology. Philadelphia: WB Saunders Company; 1995.

Accepted October 28, 2005 